\title{
Vital Signs: Preparing for Local Mosquito-Borne Transmission of Zika Virus - United States, 2016
}

\author{
CDC Zika Response
}

\begin{abstract}
On April 1, 2016, this report was posted as an MMWR Early Release on the MMWR website (http://www.cdc.gov/mmwr).
\end{abstract}

Widespread Zika virus transmission in the Region of the Americas since 2015 has heightened the urgency of preparing for the possibility of expansion of mosquito-borne transmission of Zika virus during the 2016 mosquito season (1). CDC and other U.S. government agencies have been working with state and local government partners on prevention and early detection of Zika virus infection and will increase these activities during April as part of their preparation for the anticipated emergence of mosquitoborne transmission of Zika virus in the continental United States.

Zika virus is spread primarily through the bite of infected Aedes species mosquitoes, but it can also be transmitted during sex by a man to his partners and from a pregnant woman to her developing fetus (2). The most common signs and symptoms of Zika virus disease are fever, rash, joint pain, and conjunctivitis. The illness is usually mild, with symptoms lasting from several days to a week. There is increasing evidence that Zika virus infection during pregnancy is associated with early pregnancy loss, microcephaly, and other pregnancy problems (3). CDC therefore recommends special precautions for pregnant women. Pregnant women are advised not to travel to areas with active Zika virus transmission and to consistently and correctly use condoms during sex (i.e., vaginal intercourse, anal intercourse, or fellatio) or to abstain from sex for the duration of the pregnancy with male partners who reside in or have traveled to areas with active Zika virus transmission (http://www.cdc.gov/zika/ geo/index.html). Pregnant women who live in or must travel to one of these areas should talk to their health care provider and strictly follow steps to prevent Zika virus infection acquisition from mosquito bites (http://wwwnc.cdc.gov/travel/page/avoidbug-bites) and through sexual transmission (http://www.cdc. gov/zika/transmission/sexual-transmission.html) $(4,5)$.

On April 1, 2016, CDC is hosting a 1-day Zika Action Plan Summit, which focuses on awareness and planning for U.S. state and local jurisdictions most likely to face mosquitoborne transmission of Zika virus in the coming months (๑). The Commonwealth of Puerto Rico, U.S. Virgin Islands, and American Samoa are already experiencing active mosquitoborne Zika virus transmission at varying levels (7). The U.S. government convened this summit to provide senior state and local government officials with information, plans, and tools to improve Zika preparedness, and an opportunity for them to develop effective response plans for their jurisdictions.
Persons who are planning travel should visit CDC's Travelers' Health site (http://wwwnc.cdc.gov/travel/page/zika-travelinformation) for the most up-to-date travel information. Areas with active Zika virus transmission are likely to change over time and might include locations not yet listed. CDC has published interim guidelines and additional updates on Zika virus disease and will continue sharing information as more is learned. Additional publications and resources are available (Box).

Corresponding author: Katherine Lyon Daniel for CDC Zika Response, eocjictriage2@cdc.gov, 770-488-7100.

BOX. Additional publications and resources regarding Zika virus disease

- CDC's Zika website (http://www.cdc.gov/zika/)

- MMWR Zika reports (http://www.cdc.gov/mmwr/ zika_reports.html)

- Zika virus health information resource guide, National Institutes of Health (https://disasterinfo.nlm.nih.gov/ dimrc/zikavirus.html)

- CDC's Vital Signs fact sheet on Zika virus (http:// www.cdc.gov/vitalsigns/)

\section{References}

1. CDC. Zika Virus. Atlanta, GA: US Department of Health and Human Services, CDC; 2016. http://www.cdc.gov/zika/

2. CDC. Zika virus: transmission and risks. Atlanta, GA: US Department of Health and Human Services, CDC; 2016. http://www.cdc.gov/zika/ transmission/index.html

3. Brasil P, Pereira JP Jr, Raja Gabaglia C, et al. Zika virus infection in pregnant women in Rio de Janeiro-preliminary report. N Engl J Med. Published online March 4, 2016. http://dx.doi.org/10.1056/ NEJMoa1602412

4. Petersen EE, Polen KN, Meaney-Delman D, et al. Update: interim guidance for health care providers caring for women of reproductive age with possible Zika virus exposure-United States, 2016. MMWR Morb Mortal Wkly Rep. Published online March 25, 2015. http://dx.doi. org/10.15585/mmwr.mm6512e2er

5. Oster AM, Brooks JT, Stryker JE, et al. Update: interim guidance for prevention of sexual transmission of Zika virus-United States, 2016. MMWR Morb Mortal Wkly Rep. Published online March 25, 2016. http://dx.doi.org/10.15585/mmwr.mm6512e3er

6. CDC. Zika Action Plan (ZAP) summit. Atlanta, GA: US Department of Health and Human Services, CDC; 2016. http://www.cdc.gov/zap/

7. Thomas DL, Sharp TM, Torres J, et al. Local transmission of Zika virus-Puerto Rico, November 23, 2015-January 28, 2016. MMWR Morb Mortal Wkly Rep 2016;65:154-8. http://dx.doi.org/10.15585/ mmwr.mm6506e2 